\title{
ANALISIS KINERJA PASAR KARET (Hevea Brasiliensis) DI KECAMATAN KELAYANG KABUPATEN INDRAGIRI HULU
}

\author{
Aldo Mulya Dharma, Ahmad Rifai, Evy Maharani \\ Jurusan Agribisnis Fakultas Pertanian Universitas Riau \\ Kampus Binawidya Simpang Baru Kecamatan Tampan Pekanbaru \\ Email: Mulyadharma27@gmail.com
}

\begin{abstract}
ABSTRAK
Kecamatan Kelayang adalah salah satu kecamatan yang memiliki luas areal perkebunan karet terluas yang ada di Kabupaten Indragiri Hulu, dengan luas areal perkebunan karet dikecamatan Kelayang ialah 13.066 (Ha). Penelitian ini bertujuan untuk menganalisis pemasaran karet berdasarkan saluran pemasaran dan kinerja pasar. Penelitian ini dilakukan di Kecamatan Kelayang, Kabupaten Indragiri Hulu. Penelitian ini dilakukan menggunakan metode survei. Objek penelitian adalah pedagang, pedagang besar dan lembaga pemasaran yang terlibat dalam pemasaran karet dari produsen ke konsumen akhir (pabrik) di lokasi penelitian. Jumlah sampel pedagang yang ditentukan dalam penelitian ini menggunakan metode sensus. Responden dalam penelitian ini adalah pedagang karet dengan total responden 42, total pedagang pengumpul 38, dan 4 pedagang besar. Hasil dari penelitian ini adalah (1) saluran pemasaran karet yang terdiri dari dua saluran: saluran pemasaran I dari petani, pengumpul, pedagang besar dan pabrik, dan saluran pemasaran II dari petani, pengumpul dan pabrik. ; (2) kinerja pasar di saluran pemasaran I menghasilkan marjin pemasaran sebesar Rp2.077,01 / kg, dan saluran pemasaran II Rp. Rp 2.058,8 / kg, efisiensi pemasaran saluran pemasaran sebesar $13,25 \%$, dan saluran pemasaran II 8,84\%. Saluran pemasaran saham petani I adalah $78,30 \%$, dan saluran pemasaran II adalah 78,17\%. Kinerja pasar dalam posisi tawar petani lemah karena harga ditentukan secara sepihak oleh pedagang, terutama di saluran I dan saluran II.
\end{abstract}

\section{Kata kunci: Saluran, Karet, Pemasaran Dan Kinerja}

\section{PENDAHULUAN}

Perkebunan merupakan bagian pendapatan nasional dan devisa negara Indonesia, yang dapat dilihat dari nilai ekspor komoditas perkebunan, pada Tahun 2016 total ekspor perkebunan mencapai US\$ 28,234 milyar atau setara dengan Rp. 367,040 triliun (asumsi 1 US\$ = Rp. 13.000,00). Kontribusi sub sektor perkebunan terhadap perekonomian nasional semakin meningkat dan diharapkan dapat memperkokoh pembangunan perkebunan secara menyeluruh. (Kementrian Pertanian, 2016).

Berdasarkan statistik Indonesia tahun 2017, luas areal perkebunan karet rakyat Indonesia pada tahun 2015 sebesar 3.075.600 ha dan produksi sebanyak 2.568.600 ton, sedangkan tahun 2016 terjadi peningkatan yaitu mencapai 3.087.200 ha dengan produksi sebanyak 2.575.200 ton (BPS Indonesia, 2017). Peningkatan luas lahan serta produksi karet merupakan hasil jerih payah pemerintah dan masyarakat dalam mengembangkan komoditas unggulan Indonesia.

1 | Analisis Kinerja Pasar Karet (Hevea Brasiliensis) Di Kecamatan Kelayang Kabupaten Indragiri Hulu 
Provinsi Riau sangat terkenal akan sektor perkebunannya, salah satu subsektor perkebunan yang terkenal tersebut ialah perkebunan karet. Pada tahun 2016 luas areal perkebunan karet di Provinsi Riau sebesar 496.878 ha dan produksi sebanyak 376.704 ton (BPS Provinsi Riau, 2017).

Karet merupakan salah satu komoditas perkebunan yang penting dan strategis di Provinsi Riau. Perannya cukup besar dalam mendorong perekonomian rakyat. Kabupaten Indragiri Hulu dimana jumlah produksi perkebunan karet Kabupaten Indragiri Hulu pada tahun 2015 adalah 43.951 ton dan pada tahun 2016 sebanyak 43.508 ton. Sedangkan Luas lahan Perkebunan Karet di Kabupaten Indragiri Hulu pada tahun 2015 dan 2016 yaitu 61.372 Ha tidaK adaya perubahan luas lahan karet yang ada di Kabupaten Indragiri Hulu. Kontribusi produksi karet Kabupaten Indragiri Hulu terhadapa total produksi karet provinsi Riau pada tahun 2015 sebesar 11,72\% sedangkan pada tahun 2016 sebesar 11,54\%. Terjadi penurunan produksi karet di Kabupaten Indragiri Hulu (BPS Provinsi Riau, 2017).

Kecamatan Kelayang merupakan salah satu kecamatan yang berada di Kabupaten Indragiri Hulu Provinsi Riau. Pada tahun 2016 produksi perkebunan karet di Kecamatan Kelayang 7,396 ton. Sedangkan di Kabupaten Indragiri Hulu Kecamatan Kelayang adalah Kecamatan yang memiliki luas perkebunan karet terluas Yang ada di Kabupaten Indragiri Hulu dengan luas 13,066 Ha. (BPS Kabupaten Indragiri Hulu, 2017).

Permasalahan pemasaran karet di desa ini yaitu fluktuasi harga yang selalu berubah-ubah tergantung nilai tukar rupiah (kurs) terhadap dolar di Indonesia. Harga dapat sewaktu-waktu berubah sesuai kualitas dari produksi karet tersebut. Harga karet pada tahun 2017 di Kecamatan Kelayang berkisar antara Rp 6.000,-/kg hingga Rp 6.800,-/kg dan harga cenderung menunjukkan penurunan. Diasumsikan bahwa penurunan harga ini dikarenakan kebutuhan karet dunia yang tidak mengalami peningkatan sehingga menjadikan stok karet saat ini dipasar Internasional melimpah. Sementara supply karet terus didorong hingga akhirnya terjadi overstock, hal ini mempengaruhi harga yang akhirnya menjadi turun sesuai dengan kurva penawaran.

\section{METODE PENELITIAN}

Penelitian ini dilaksanakan di Kecamatan Kelayang, Kabupaten Indragiri Hulu, Provinsi Riau dengan pertimbangan bahwa daerah tersebut merupakan daerah salah satu sentra produksi karet terbesar yang ada di Kabupaten Indragiri Hulu. Penelitian dilakukan pada bulan Februari 2018 hingga bulan Juli 2018.

Penelitian ini dilakukan dengan menggunakan metode survei. Objek penelitian adalah pedagang pengumpul, pedagang besar dan lembaga-lembaga pemasaran yang terlibat dalam pemasaran karet mulai dari produsen sampai ke konsumen akhir (pabrik) di lokasi penelitian. 
Jumlah sampel pedagang yang ditetapkan pada penelitian ini menggunakan metode Sensus. Metode ini digunakan atas dasar populasi tidak diketahui dengan pasti namun tetap dengan kriteria yaitu pedagang yang membeli karet di Kecamatan Kelayang. Sampel yang diambil adalah sampel pedagang pengumpul dan pedagang besar yang ada di Kecamatan Kelayang. Sampel yang diambil berjumlah 42 responden pedagang karet di Kecamatan Kelayang yang terdiri dari 38 responden pedagang pengumpul dan 4 responden pedagang besar yang ada di Kecamatan Kelayang . Sampel pedagang besar di peroleh dari informasi yang didapat dari pabrik penjualan karet. Selanjutnya sampel pedagang pengumpul didapat dari informasi pedagang besar. Penilitian ini tidak mengambil sampel petani, namun hanya menggunakan data harga pembelian karet oleh pedagang pengumpul.

Jenis dan sumber data yang digunakan dalam penelitian ini yaitu: data primer dan data sekunder. Data primer yang diperlukan dari petani sampel adalah umur, pendidikan, pengalaman berusahatani dan tanggungan keluarga, karakteristik usaha tani, luas lahan, cara pemasaran dan cara penetapan harga pada saat menjual hasil produksi. Data sekunder yang diambil adalah data daerah penelitian meliputi letak, keadaan geografis, data produksi karet, keadaan daerah penelitian, jumlah penduduk, pendidikan, mata pencaharian, sarana dan prasarana serta data-data lain yang mendukung penelitian.

Tujuan pertama mengenai saluran pemasaran dianalisis secara deskriptif dengan cara menelusuri jalur pemasaran karet mulai dari produsen (petani) sampai ke konsumen. Pada penelitian ini, saluran pemasaran yang diteliti dimulai dari pedagang pengumpul, pedagang besar yang ada di Kecamatan Kelayang dan kemudian Pabrik PT. Tirta Sari Rengat.

Tujuan kedua dianalisis dengan analisis kuantitatif dengan perhitungan margin pemasaran, Farmer's Share dan efisiensi pada masing-masing lembaga pemasaran.

\section{Margin Pemasaran}

Margin pemasaran adalah selisih dari harga yang dibayar konsumen akhir dengan harga yang diterima petani (Sugiyono, 2010). Untuk menghitung margin pemasaran digunakan rumus yaitu:

$$
\mathrm{MP}=\mathrm{Hp}-\mathrm{Hb}
$$

Keterangan:

$\mathrm{MP}=$ Margin Pemasaran $(\mathrm{Rp} / \mathrm{Kg})$

$\mathrm{Hp}=$ Harga penjualan $(\mathrm{Rp} / \mathrm{Kg})$

$\mathrm{Hb}=$ Harga pembelian $(\mathrm{Rp} / \mathrm{Kg})$

3 | Analisis Kinerja Pasar Karet (Hevea Brasiliensis) Di Kecamatan Kelayang Kabupaten Indragiri Hulu 


\section{Farmer's Share}

Farmer's share merupakan perbedaan antara harga di tingkat produsen dan konsumen untuk karet Ini merupakan porsi dari nilai yang dibayar konsumen akhir yang diterima oleh petani, dalam bentuk persentase (\%) (Asmarantaka 2012 dalam Herdian 2016). Farmer's share adalah perbandingan bagian yang didapat oleh petani, dapat dirumuskan dengan:

$\mathrm{Fs}=\frac{\mathrm{Pf}}{\mathrm{Pr}} \times 100 \%$

Keterangan:

Fs = Bagian harga yang diterima petani karet $(\%)$

$\mathrm{Pf}=$ Harga karet di tingkat petani $(\mathrm{Rp} / \mathrm{kg})$

$\operatorname{Pr}=$ Harga karet di tingkat konsumen akhir $(\mathrm{Rp} / \mathrm{kg})$

3. Efisiensi pemasaran

Efisiensi pemasaran adalah perbandingan antara total biaya pemasaran terhadap total nilai produk (harga beli pada konsumen). Untuk menghitung efisiensi pemasaran (Soekartawi, 2002) :

$$
\text { Eps }=\frac{T B}{T N P} \times 100 \%
$$

Keterangan:

Eps $\quad=$ Efisiensi pemasaran $(\%)$

$\mathrm{TB}=$ Total Biaya pemasaran $(\mathrm{Rp} / \mathrm{Kg})$

$\mathrm{TNP}=$ Total Nilai Produk $(\mathrm{Rp} / \mathrm{Kg})$

\section{HASIL DAN PEMBAHASAN}

Kabupaten Indragiri Hulu merupakan Kabupaten yang memiliki potensi dibidang perkebunan yang cukup besar dan dapat terus untuk dikembangkan. Salah satu Kecamatan di Kabupaten Indragiri Hulu yang memiliki luas areal perkebunan yang cukup luas adalah Kecamatan Kelayang. Beberapa tanaman perkebunan yang ada di Kecamatan Kelayang adalah tanaman karet, tanaman kakao, tanaman kelapa sawit, dan ada beberapa tanaman lainnya. Kecamatan Kelayang Merupakan Kecamatan dengan luas perkebunan karet terbesar yang ada di kabupaten Indragiri Hulu dengan luas areal perkebunan karet 13.066 Ha, diikuti dengan luas areal perkebunan kelapa $227 \mathrm{Ha}$, luas areal perkebunan Kelapa Sawit 1.107 Ha.

\section{Saluran Pemasaran}

Saluran pemasaran dianalisis secara deskriptif, yaitu dengan melihat aliran yang dilalui oleh lembaga-lembaga pemasaran yang ada dalam proses pemasaran hasil produksi karet mulai dari petani hingga sampai ke konsumen akhir. Petani karet di lokasi penelitian tidak bisa menjual 4 | Analisis Kinerja Pasar Karet (Hevea Brasiliensis) Di Kecamatan Kelayang Kabupaten Indragiri Hulu 
langsung hasil produksinya ke konsumen akhir disebabkan karena berbagai keterbatasan yang dimiliki oleh petani. Oleh karena itu petani membutuhkan lembaga pemasaran yang menyalurkan hasil produksi mereka sampai ke konsumen akhir. Panjang pendeknya saluran pemasaran akan berpengaruh pada harga yang akan diterima oleh petani sebagai produsen. Dari hasil penelitian diketahui ada dua jenis saluran pemasaran karet, mulai dari produsen sampai ke konsumen. Saluran pemasaran karet dapat dilihat pada Gambar 1.

33 jiwa $(78,57 \%)$

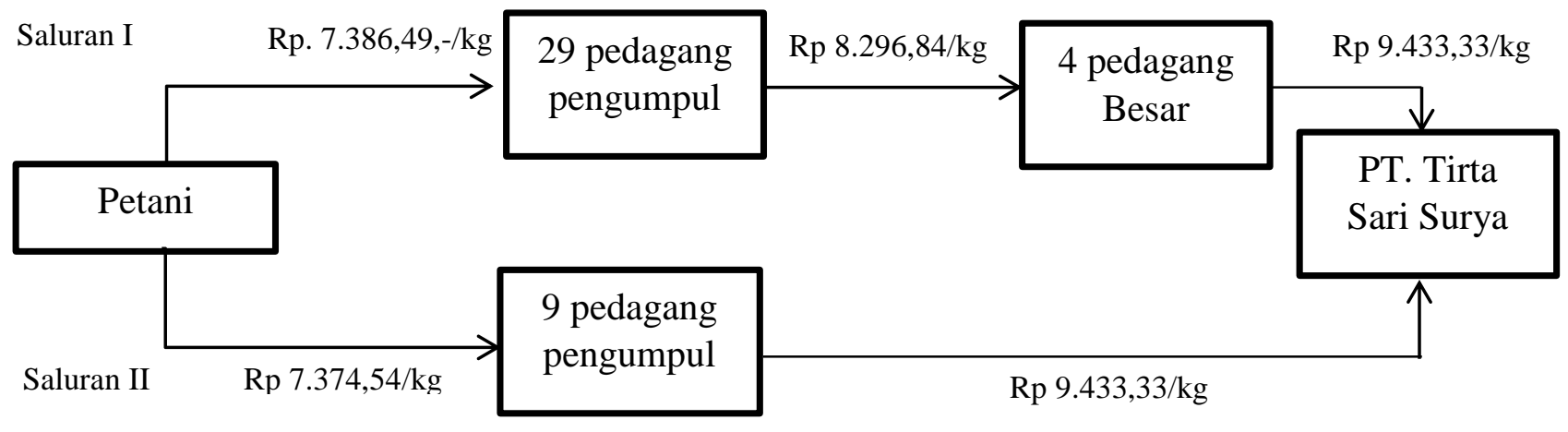

9 jiwa $(21,43 \%)$

Saluran pemasaran karet di Kecamatan Kelayang diketahui ada dua saluran pemasaran yaitu saluran pemasaran I, dimana pada saluran ini petani menjual melalui pedagang pengumpul, pedagang besar dan kemudian ke Pabrik PT. Tirta Sari Surya. Rata-rata harga jual petani karet saluran I yaitu $\mathrm{Rp} 7.386,49,-/ \mathrm{kg}$, harga jual 29 pedagang pengumpul pada saluran I Rp 8.296,84/kg, dan harga jual 4 pedagang besar ke pabrik pada saluran pemasaran I Rp 9.433,33/kg. Sedangkan Saluran pemasaran ke II, dimana petani menjual karet ke pedagang pengumpul kemudian pedagang pengmpul langsung menjual karet tesebut ke PT. Tirta Sari surya. Rata-rata harga jual petani saluran pemasaran ke II Rp 7.374,54/kg, harga jual 9 pedagang pengumpul pada saluran ke II ke pabrik yaitu Rp 9.433,33/kg.

Persentase pedagang responden di Kecamatan Kelayang yang menjual melalui saluran pemasaran I sebanyak 33 orang $(78,57 \%)$, dan yang menjual melalui saluran pemasaran II sebanyak 9 orang $(21,43 \%)$.

\section{Penampilan atau Kinerja Pasar}

Penampilan pasar dilihat dari beberapa pendekatan, antara lain margin pemasaran, biaya pemasaran, kentungan lembaga pemasaran, bagian yang diterima petani (Farmer's share) dan efisiensi pemasaran. 


\section{Margin Pemasaran}

Analisis pemasaran sering menggunakan konsep margin pemasaran yang dipandang dari sisi harga, sehingga margin pemasaran merupakan selisih harga yang dibayar konsumen akhir dan harga yang diterima petani produsen (Sudiyono, 2001).

Margin adalah selisih harga yang dibayarkan oleh konsumen akhir dengan harga yang diterima produsen, disini yang bertindak sebagai konsumen adalah pabrik dan produsennya adalah petani karet yang ada di Kecamatan Kelayang. Margin pemasaran dapat di lihat dari saluran pemasaran yang dilakukan, dalam penelitian ini terdapat dua saluran pemasaran Karet di Kecamatan Kelayang

Tabel 1. Margin pemasaran saluran pemasaran I dan saluran pemasaran II di Kecamatan Kelayang tahun 2017

\begin{tabular}{|c|c|c|c|c|c|c|}
\hline \multirow[b]{2}{*}{ No } & \multicolumn{3}{|c|}{ Saluran Pemasaran I } & \multicolumn{3}{|c|}{ Saluran Pemasaran II } \\
\hline & Uraian & $\begin{array}{c}\text { Harga } \\
\text { Jual/Beli }\end{array}$ & $\begin{array}{c}\text { Biaya } \\
(\mathrm{Rp} / \mathrm{Kg})\end{array}$ & Uraian & $\begin{array}{c}\text { Harga } \\
\text { Jual/Beli }\end{array}$ & $\begin{array}{c}\text { Biaya } \\
(\mathrm{Rp} / \mathrm{Kg})\end{array}$ \\
\hline 1 & Petani & & & Petani & & \\
\hline & a.Harga Jual & $7.386,49$ & & a.Harga Jual & $7.374,53$ & \\
\hline 2 & Pedagang Pengumpul & & & Pedagang Pengumpul & & \\
\hline & a.Harga Beli & $7.386,49$ & & a.Harga Beli & $7.374,53$ & \\
\hline & b.Harga jual & $8.296,84$ & & b. Harga Jual & $9.433,33$ & \\
\hline & c.Biaya Pemasaran & & & c. Biaya Pemasaran & & \\
\hline & Transportasi & & 39,24 & Transportasi & & 52,50 \\
\hline & Pengangkutan & & 150,00 & Pengangkutan & & 200,00 \\
\hline & Bongkar/Muat & & 50,00 & Bongkar/Muat & & 100,00 \\
\hline & Komunikasi & & 5,00 & Komunikasi & & 10,00 \\
\hline & Penyusutan 5\% & & 369,32 & Penyusutan $5 \%$ & & 368,72 \\
\hline & Total Biaya & & 613,56 & Total Biaya & & 731,22 \\
\hline & d. Margin Pemasaran & 910,35 & & d. Margin Pemasaran & $2.058,8$ & \\
\hline & e. keuntungan & 296.79 & & e. Keuntungan & $1.327,58$ & \\
\hline
\end{tabular}

3 Pedagang Besar
a. Harga Beli
$8.266,67$
b. Harga Jual
$9.433,33$
c. Biaya Pemasaran

Transportasi

9,6

Bongkar Muat

100,00

Komunikasi

10,00

Penyusutan 5\%

413,33

Total Biaya

532,93

6 | Analisis Kinerja Pasar Karet (Hevea Brasiliensis) Di Kecamatan Kelayang Kabupaten Indragiri Hulu 


\begin{tabular}{llllc} 
& d. Margin Pemasaran & $1.166,66$ & & \\
& e. Keuntungan & 633,73 & & \\
\hline 4 & Pabrik & & Pabrik \\
& a.Harga Beli & $9.433,33$ & a.Harga Beli & $9.433,33$ \\
\hline 5 & Total Margin & $2.077,01$ & Total Margin & $2.058,8$ \\
\hline 6 & Total Biaya Pemasaran & $1.146,49$ & Total Biaya Pemasaran & 834,17 \\
\hline 7 & Total Keuntungan & 930,52 & Total Keuntungan & $1.327,58$ \\
& Lembaga Pemasaran & & Lembaga Pemasaran & 78,17 \\
\hline 8 & Farmer's Share $(\%)$ & 78,30 & Farmer's Share $(\%)$ & 8,84 \\
\hline 9 & Efisiensi Pemasaran $(\%)$ & 13,25 & Efisiensi Pemasaran $(\%)$ & \\
\hline
\end{tabular}

Saluran pemasaran I menunjukkan bahwa rata-rata harga jual karet petani di Kecamatan Kelayang sebesar Rp 7.386,49,-/kg. Pedagang pengumpul menanggung biaya pemasaran sebesar Rp 613,56,-/kg dengan keuntungan yang diperoleh Rp. 296.79,-/kg dan marjin pemasaran sebesar Rp 910,35,-/kg. Harga jual ke pedagang besar rata-rata Rp 8.296,84,-/kg. Pedagang besar menanggung biaya pemasaran sebesar Rp 532.93,-/kg dengan keuntungan diperoleh sebesar Rp 633,73,-/kg dan marjin pemasaran sebesar Rp 1.166,66,-/kg. Harga jual pedagang besar ke pabrik rata-rata sebesar Rp 9.433,33,-/kg. Harga ini berfluktuatif bergantung pada ketersediaan karet pada kondisi tertentu. Efisiensi pemasaran diperoleh sebesar $13,25 \%$ relatif cukup besar. Hal ini disebabkan oleh tingkat keuntungan pemasaran, harga beli pabrik, ketersediaan fasilitas fisik pemasaran, kompetisi dan peranan lembaga pemasaran yang terlibat.

Saluran pemasaran II menunjukkan bahwa total margin pemasaran diperoleh sebesar $\mathrm{Rp}$ 2.058,8/kg Margin ini diperoleh dari rata-rata harga beli pedagang pengumpul dengan harga sebesar Rp 7.374,53/kg kemudian pedagang pengumpul menjual dengan harga sebesar $\mathrm{Rp}$ 9.433,33/kg kepada pabrik. Pada saluran II pedagang pengumpul langsung menjual karet ke komsumen akhir (pabrik). Total biaya pemasaran pada saluran pemasaran kedua Rp 834,17,-/kg dengan total keuntungan lembaga pemasaran yang didapat sebesar Rp 1.327,58/kg

\section{Efisiensi saluran pemasaran}

Bagian yang diterima petani berhubungan negatif dengan margin pemasaran, artinya semakin tinggi margin pemasaran maka bagian yang akan diterima petani semakin rendah (Meryani, 2008). Adapun kriteria bagian yang diterima petanimenurut Downey dan Erickson dalam Putri (2014) yaitu (1) FS >40\% = Efisien; (2) FS <40\% = Tidak Efisien..

Hasil yang didapat bahwa saluran pemasaran II lebih efisien dibandingkan dengan saluran pemasaran I karena saluran II tidak melalui lembaga pemasaran yaitu pedagang besar melainkan petani langsung menjual kepada pedagang pengumpul kemudian pedagang pengumpul langsung menjual ke 7 | Analisis Kinerja Pasar Karet (Hevea Brasiliensis) Di Kecamatan Kelayang Kabupaten Indragiri Hulu 
pabrik dengan harga yang sama dengan harga yang ditetapkan oleh pabrik terhadap pedagang Besar pada saluran I. jadi harga yang didapat pedagang pengumpul pada saluran II yaitu $100 \%$ tanpa ada potongan yang besar dari pedagang Besar. Berdasarkan table 1 saluran pemasaran I efisiensi pemasaran yang didapat adalah $13,25 \%$ pada saluran pemasaran II sebesar $8,84 \%$. Hal ini menunjukkan bahwa pemasaran karet di kedua saluran layak untuk diusahakan. Saluran pemasaran karet yang efisien ditemukan pada saluran pemasaran II yang di lakukan oleh pedagang pengumpul yang menjual karetnya langsung ke pabrik.

\section{Keuntungan lembaga pemasaran}

Keuntungan lembaga pemasaran di Kecamatan kelayang. Total keuntungan yang diterima oleh lembaga pemasaran di Kecamatan Kelayang dilihat dari saluran pemasaran yang digunakan oleh lembaga pemasaran, pada saluran pemasaran I pedagang pengumpul memperoleh keuntungan sebesar Rp 296.79/kg dan pedagang besar sebesar Rp 633.73/kg, total keuntungan pada saluran pemasaran I sebesar Rp 930,52/kg. Keuntungan pada saluran pemasaran II pedagang pengumpul memperoleh keuntungan Rp 1327,58/kg, pada saluaran pemasaran II hanya ada satu lembaga pemasaran yang terlibat, yaitu pedagang pengumpul. Jadi total keuntungan yang terbesar dari dua saluran pemasaran adalah saluran ke II.

\section{Bagian yang diterima petani (Farmer's Share)}

Bagian yang diterima petani karet dihitung dengan melihat perbandingan antara bagian harga pada petani dengan harga pada konsumen akhir. Dari hasil penelitian di ketahui bahwa bagian yang diterima petani pada saluran pemasaran I adalah sebesar 78,30\% dengan penerimaan sebesar Rp 7.386,49/kg (Tabel 1). Saluran I terdapat 2 lembaga pemasaran yang terlibat yaitu pedagang pengumpul dan pedagang besar. Pada saluran II bagian yang diterima petani sebesar 78,17\% dengan penerimaan Rp 7.374,53/kg (Tabel 1). Lembaga pemasaran yang terlibat dalam saluran pemasaran II hanya satu yaitu pedagang pengumpul. Hasil perhitungan pada ke dua saluran pemasaran di Kecamatan Kelayang menunjukkan bahwa saluran pemasaran II yang memiliki lebih sedikit lembaga pemasaran dan memiliki farmer's share atau bagian yang diterima petani yang lebih kecil dibandingan saluran pemasaran I. hal ini di karenakan penetapan harga dibagian petani sehingga penerimaan petani di saluran II lebih kecil dari pada penerimaan petani pada saluran pemasaran I. 


\section{KESIMPULAN}

\section{Kesimpulan}

Berdasarkan hasil analisis dan pembahasan dapat diambil kesimpulan dari penelitian ini sebagai berikut :

1). Terdapat dua saluran pemasaran karet yang ada di Kecamatan Kelayang. Saluran pertama (I) yaitu petani karet menjual karetnya ke pedagang pengumpul kemudian pedagang pengumpul menjual ke pedagang besar dan pedagang besar menjual ke pabrik pengolahan karet. Dan Saluran ke dua (II) petani karet menjual karetnya ke pedagang pengumpul kemudian pedagang pengumpul menjual karetnya ke pabrik.

2). Kinerja pasar karet di Kecamatan Kelayang sebagai berikut:

a) Total margin pemasaran Karet Di kecamatan kelayang adalah adalah Rp. 2.077,01,-/kg pada saluran pemasaran I dan Rp2.058,8,-/kg pada saluran pemasaran II.

b) Total keuntungan lembaga pemasaran di Kecamatan Kelayang adalah Rp 827,66,-/kg pada saluran pemasaran ke I dan 1176,27,-/kg pada saluran pemasaran ke II. Farmer's share saluran pemasaran I sebesar $78.30 \%$ dengan penerimaan sebesar Rp 7.386,49/kg, dan saluran pemasaran II sebesar $78.17 \%$ dengan penerimaan Rp 7374,53/kg. Nilai efisiensi pemasaran yang makin rendah (kecil) menunjukkan bahwa, tingkat efisiensi pemasaran suatu komoditi makin tinggi dan jika nilai tersebut semakin besar (tinggi) maka dikatakan sistem pemasaran yang sedang berjalan tingkat efisiensi operasional yang semakin rendah. (Soekartawi, 2002). Maka dapat disimpulkan bahwa saluran pemasaran II lebih efisien dibandingkan dengan saluran pemasaran I.

\section{Saran}

Perlu adanya penyediaan informasi mengenai harga karet yang berlaku di tingkat petani, pedagang dan pabrik, serta harus disebar luaskan sampai ke tingkat petani, sehingga posisi tawar menawar lebih kuat untuk meningkatkan harga karet di tingkat petani.

\section{DAFTAR PUSTAKA}

Asrol, \& Heriyanto. 2019. Structures of revenue, expenditure, and welfare of household farmers in kampar regency, riau indonesia. WSEAS Transactions on Business and Economics, 16, 1-8. Retrieved from www.scopus.com

BPS Riau. 2017. Riau Dalam Angka 2017. Badan Pusat Statistik Provinsi Riau. Pekanbaru.

BPS Kabupaten Indragiri Hulu.2017. Indragiri Hulu Dalam Angka 2017. Badan Pusat Statistik Kabupaten Indragiri Hulu.

Heriyanto, H., \& Darus, D. 2017. Analisis Efisiensi Faktor Produksi Karet di Kabupaten Kampar Provinsi Riau. Dinamika pertanian, 33(2), 1-10.

9 | Analisis Kinerja Pasar Karet (Hevea Brasiliensis) Di Kecamatan Kelayang Kabupaten Indragiri Hulu 
Heriyanto, H., Asrol, A., Karya, D., \& Ningsih, V. Y. (2018). Analisis Faktor Produksi Kalapa Sawit Rakyat Menurut Tipologi Lahan di Kabupaten Indragiri Hilir Provinsi Riau. Jurnal Lahan Suboptimal, 7(1).

Heriyanto, H., Karya, D., Choanji, T., Asrol, A., Bakce, D., \& Elinur, E. (2019). Regression Model in Transitional Geological Environment For Calculation Farming and Production of Oil Palm Dominant Factor in Indragiri Hilir Riau Province. Journal of Geoscience, Engineering, Environment, and Technology, 4(1), 56-65.

Maryani. 2007. Aneka Tanaman Perkebunan, Pusat Pengembangan Universitas Riau.

Pekanbaru.

Soekartawi, 1993. Prinsip Dasar Manajemen Pemasaran Hasil - Hasil Pertanian Teori dan Aplikasinya. Raja Grafindo Persada. Jakarta.

Sudiyono A. 2001. Pemasaran Pertanian. Universitas Muhammadiyah Malang.

10 | Analisis Kinerja Pasar Karet (Hevea Brasiliensis) Di Kecamatan Kelayang Kabupaten Indragiri Hulu 